\title{
Atitudes linguísticas de estudantes universitários: o fenômeno da monotongação em foco
}

\section{Linguistic attitudes of university students: the phenomena of monophthongization in focus}

\author{
Andréia Silva Araujo ${ }^{1}$ \\ Damiana Karina Vieira Borges ${ }^{2}$
}

Resumo: À luz dos pressupostos teóricos da Sociolinguística Variacionista (WEINREICH; LABOV; HERZOG, 2006; LABOV, 2008) e da Psicologia Social (LAMBERT; LAMBERT, 1972), neste trabalho, objetivamos identificar as crenças e as atitudes linguísticas de 60 estudantes da Universidade Federal de Sergipe, Campus Prof. Alberto Carvalho - Itabaiana/SE, perante o fenômeno da monotongação dos ditongos decrescentes ("ouro" "oro") e crescentes ("ciência" "ciênça"). Para tanto, a coleta dos dados foi feita a partir da aplicação de um questionário de atitudes linguísticas composto por seis perguntas subjetivas/abertas sobre cada tipo de monotongação para verificar se os falantes possuem uma avaliação positiva ou negativa sobre o fenômeno em estudo. Os resultados evidenciaram que os estudantes, tendo consciência ou não da redução da semivogal no ditongo decrescente, apresentam posicionamento positivo quanto ao fenômeno e acreditam que ele acontece independentemente de a pessoa ser escolarizada ou não. Diferentemente acontece quando a redução ocorre em ditongo crescente: os estudantes têm uma visão negativa desse fenômeno e acreditam que as pessoas podem sofrer alguma coerção social, corroborando, assim, com os resultados dos estudos sociolinguísticos de que os fenômenos mais salientes são os mais estigmatizados.

Palavras-chave: Monotongação; Atitude linguística; Itabaiana/SE.

Abstract: By light of the theoretical presupposes of the variant sociolinguistic (WEINREICH; LABOV; HERZOG, 2006; LABOV, 2008) and of the social psychology (LAMBERT; LAMBERT, 1972), in this work, we aimed to identify beliefs and linguistics attitudes of 60 students of the Universidade Federal de Sergipe, Campus Prof. Alberto Carvalho - Itabaiana/SE, in front of the monophthongization phenomena of the decreasing diphthongs ("ouro" "oro") and growing ("ciência" "ciênça"). For this purpose, data collection was done by questionnaire application of linguistic attitudes composed by six questions subjective/open about each type of monophthongization to analyze if the speakers have a positive or negative perception about the phenomena studied. The results highlighted that the students, having in mind or not of the semivowel reduction in the decreasing diphthong, showed positive position about the phenomena and believe that it happens independently if the is educated or not. Differently happen when the reduction occurs in growing diphthong: the students have a negative perception of these phenomena and belive that the people can suffer some social coercion, affirming the results of the sociolinguistic studies of the phenomena more salient are the most stigmatized.

Keywords: Monophthongization; Linguistic attitude; Itabaiana/SE.

\footnotetext{
1 Doutoranda em Estudo Linguísticos pelo Programa de Pós-graduação em Letras da Universidade Federal de Sergipe. E-mail: andreialuzinete@hotmail.com.

2 Graduanda em Letras Português pela Universidade Federal de Sergipe - Campus Prof. Alberto Carvalho. E-mail: karinabritney22@hotmail.com.
} 


\section{Introdução}

No transcorrer das nossas vidas, mantemos contato com pessoas de comunidades distintas, tanto na de que fazemos parte quanto fora desta, e, nesse percurso, percebemos a maneira diferente do falar de cada um. Até mesmo entre falantes que possuem a mesma variedade linguística, é possível perceber que, em maior ou menor grau, nenhum indivíduo fala exatamente igual ao outro. Vários fatores contribuem para que as variedades se diferenciem e para que sejam usadas ou não pelo falante, como, por exemplo, a origem regional, a escolaridade, a classe social, a situação comunicativa, seja formal (uma entrevista de emprego), seja informal (uma conversa entre amigos), e, também, as crenças e as atitudes linguísticas.

Estudar as crenças e as atitudes linguísticas dos falantes é uma forma de mensurar e "compreender o seu comportamento linguístico e as avaliações que eles fazem sobre fenômenos da língua. No português brasileiro, há fenômenos linguísticos em variação mais estigmatizados (como o rotacismo: "blusa" "brusa"), que estão no nível de avaliação social dos estereótipos (LABOV, 2008 [1972]), e menos estigmatizados (como a supressão do \d\ em gerúndio: "fazendo" "fazeno"), que estão no nível de apreciação social dos marcadores - razoavelmente sensíveis à avaliação - ou dos indicadores - com pouca força avaliativa (LABOV, 2008 [1972]). Isso ocorre pelo fato de os falantes julgarem as formas como de prestígio ou desprestígio a partir de convenções linguísticas, sociais ou ideológicas e, ao adquirirem uma visão mais negativa e estereotipada de algum fenômeno variável, principalmente dos mais salientes (perceptíveis), acabam apresentando preferência por uma forma linguística em detrimento de outra.

Um dos fenômenos linguísticos em variação, no português, é a monotongação, que consiste na redução da semivogal do ditongo, por exemplo, nos ditongos crescentes ("ciênça" "ciência", "poliça" "polícia"); decrescentes ("pexe" "peixe", "poco" "pouco" e "caxa" "caixa"); e nasais ("onti" "ontem", "passaru" "passaram"). Dentre esses tipos de monotongação, focalizamos, nesta pesquisa, as que ocorrem em ditongos crescentes e decrescentes.

Em relação aos ditongos decrescentes, estudos mostram que: os ditongos mais favoráveis à monotongação são os ditongos [ej], [ow] e [aj], mas, dentre estes, o que mais sofre redução da semivogal é o ditongo [ow] (cf. LOPES, 2002); e a supressão do glide tem sido demonstrada cada vez mais independentemente de fatores linguísticos e extralinguísticos (FARIAS; OLIVEIRA, 2003). Já em ditongos crescentes (paciência paciênça, edifício edifíçu ou em série seri, árduo árdu), a redução neste contexto pode estar relacionada com a escolaridade do falante (cf. HORA, 2012). Isso significa que os falantes com menos escolaridade podem aplicar a regra de monotongação tanto em contextos, como em paciência paciênça quanto em "série" "séri" e os mais escolarizados terão mais chances de aplicá-

la em contextos em que a saliência entre as vogais é menos perceptível, como em "espécie" "espéci", "árduo" "árdu". Tal fato ocorre porque o alçamento de "e" e "o" para "i" e "u", respectivamente, é comum no português brasileiro e mais aceito também.

Muitos estudos já foram feitos sobre a monotongação de ditongos, dentre eles: Hora (2012), Cristófaro Silva (2014) e Moura (2017), sobre a monotongação do ditongo crescente; e Lopes (2002), 
Pereira (2004), Amaral (2005), Toledo (2011), Santiago (2017) etc sobre a redução dos ditongos decrescentes. Esses autores, com exceção de Moura (2017) e de Santiago (2017), apenas fizeram seus estudos focalizando a redução do fenômeno, considerando os fatores linguísticos e extralinguísticos, evidenciando, assim, a necessidade de realizar um estudo de atitude sobre o fenômeno em estudo.

A partir dessa constatação, surgiram os seguintes questionamentos: quais as atitudes linguísticas dos falantes frente ao fenômeno da monotongação e como eles o julgam? Será que as crenças e as atitudes dos falantes sobre a monotongação em ditongos crescentes ("poliça" "polícia") e decrescentes ("oro" "ouro") são distintas? Com o intuito de responder a tais indagações, objetivamos, neste artigo, identificar as crenças e as atitudes linguísticas dos estudantes da Universidade Federal de Sergipe, Campus Prof. Alberto Carvalho - Itabaiana/SE, em relação ao fenômeno da monotongação em ditongos crescentes e decrescentes. Para tanto, desenvolvemos a pesquisa à luz dos pressupostos teóricos da Sociolinguística Variacionista (WEINREICH; LABOV; HERZOG, 2006; LABOV, 2008) e da Psicologia Social (LAMBERT; LAMBERT, 1972),

Na seção a seguir, discutimos sobre crenças e atitudes linguísticas; em seguida, apresentamos os procedimentos metodológicos; os resultados e discussão a respeito da pesquisa; e, por fim, nossas considerações finais.

\section{Crenças e atitudes linguísticas}

A escolha e o uso de uma forma linguística estão intrinsecamente ligados ao grau de consciência social que os falantes possuem desta, ou seja, as crenças e as atitudes linguísticas que os falantes possuem frente a uma determinada variedade linguística podem influenciar o uso ou não dela. Por isso, estudar as crenças e as atitudes linguísticas dos falantes é uma forma significativa de compreender o funcionamento da língua. Isso porque ela também está sujeita à valoração, negativa ou positiva, o que pode interferir no processo de variação e mudança linguística (cf. WEINREICH; LABOV; HERZOG, 2006 [1968]). Nesse sentido, apesar de pouco explorada, a noção de crença e atitude linguística é de suma importância para os estudos sociolinguísticos (cf. BOTASSINI, 2015).

As atitudes linguísticas podem ser entendidas como o julgamento - positivo ou negativo - que 0 falante faz quanto aos usos da língua. Estas exercem "uma função essencial na determinação do nosso comportamento; por exemplo, afetam nossos julgamentos e percepções sobre os outros, ajudam a determinar os grupos sociais que nos associamos, as profissões que finalmente escolhemos e até a filosofia à sombra das quais vivemos" (LAMBERT; LAMBERT, 1972, p. 78). Ademais, a atitude é um construto mental, psicológico, difícil de definir e de mensurar, comportada de uma estrutura múltipla, formada por elementos afetivo (emoções e sentimentos), cognitivo (inclui as percepções, as crenças e os estereótipos que estão presentes no indivíduo) e comportamental (tendência a atuar e agir de certa maneira com respeito ao objeto) (LÓPEZ MORALES, 2004 apud BOTASSINI, 2015, p. 114). A atitude, no nosso caso, quanto ao fenômeno da variação, além de prever um determinado comportamento linguístico que os falantes terão sobre ele, possibilita saber a avaliação que os falantes fazem da própria língua.

Labov (2008[1972], p. 360) classifica três níveis de consciência ou de reação, relacionados ao processo de variação/mudança linguística, de acordo com o tipo de avaliação que eles recebem, a saber: 
indicadores, marcadores e estereótipos. Os indicadores "são traços linguísticos encaixados numa matriz social, exibindo diferenciação segundo a idade e o grupo social, mas não exibem nenhum padrão de alternância estilística e parecem ter pouca força avaliativa" (LABOV, 2008[1972], p. 360). Neste tipo, os traços estão abaixo do nível de consciência e ocorrem quando a mudança linguística está no início da implementação. A título de exemplificação de indicador, temos, no português, a realização do pronome sujeito no português brasileiro. Já os marcadores "exibem estratificação estilística tanto quanto estratificação social. Embora possam estar abaixo do nível da consciência, produzirão respostas regulares em testes de reação subjetiva" (LABOV, 2008[1972], p. 360), como é o caso da supressão do \d\em gerúndio: "fazendo" "fazeno". Dessa forma, a avaliação da variável é feita de forma mais consciente pelo falante, sendo que uma das variantes passa a ter status de prestígio sem que a(s) outra(s) seja(m) abertamente rejeitada(s). Há, neste caso, a implicação de diferença social bem como de correlação a grupos sociais e a estilos de fala, surgindo quando a mudança linguística já está bem adiantada. Quanto aos estereótipos, estes "são formas socialmente marcadas, rotuladas enfaticamente pela sociedade" (LABOV, 2008[1972], p. 360), como, por exemplo, o rotacismo: blusa brusa. Existe um aumento no nível de consciência dos falantes e, em virtude disso, eles, geralmente, utilizam a variante padrão nas situações mais formais para não sofrerem estigma social.

Ademais, as atitudes linguísticas são formadas por crenças, pensamentos, emoções e reações, as quais são adaptadas ao contexto social (LAMBERT; LAMBERT, 1972). As crenças podem ser definidas como "um conjunto uniforme de atitudes frente à linguagem que são partilhadas por quase todos os membros da comunidade de fala, seja no uso de uma forma estigmatizada ou prestigiada da língua em questão" (LABOV, 2008 [1972], p. 176). Além disso, as crenças de um determinado grupo social são um conjunto de normas linguísticas impostas culturalmente a cada falante desse grupo.

Cabe ressaltar que as crenças frente uma determinada variedade linguística também podem desencadear julgamentos sobre o falante ou sobre sua participação no grupo social (cf. MARQUES; BARONAS, 2015), isto é, os falantes, muitas vezes, podem ser avaliados socialmente pelo repertório verbal que trazem consigo, caracterizando sua fala ou variedade dialetal como de prestígio ou desprestígio. Tal fato pode ocorrer porque a noção de crença também pode ser entendida como "uma forma de pensamento, construções da realidade, maneiras de ver e perceber o mundo e seus fenômenos, coconstruídas em nossas experiências resultantes de um processo interativo de interpretação e (re)significação" (BARCELOS, 2007, p. 113). Em outras palavras, os indivíduos moldam seus pensamentos ou aquilo em que acreditam ao longo de suas experiências no contexto social, em que as pessoas, ao interagirem e compartilharem suas vivências, também modificam suas crenças no que acreditam ou como percebem e veem o mundo em que vivem. E, em relação à língua e aos fenômenos linguísticos, não seria diferente. Portanto, existe uma ordenação valorativa das variedades linguísticas em uso, que reflete a hierarquia dos grupos sociais" (ALKMIM, 2012, p. 41). Por isso, em nosso trabalho, pretendemos analisar as crenças e as atitudes linguísticas que os falantes exprimem sobre o fenômeno da monotongação em ditongos crescentes e decrescentes.

\section{Procedimentos metodológicos}


Para desenvolvermos a presente pesquisa, coletamos as atitudes linguísticas de 60 estudantes (30 homens e 30 mulheres) da Universidade Federal de Sergipe, Campus Prof. Alberto Carvalho Itabaiana/SE, a respeito do fenômeno da monotongação em ditongos crescentes e decrescentes. A coleta foi realizada a partir da aplicação de um questionário composto por seis perguntas subjetivas/abertas sobre cada tipo de monotongação para verificar se os falantes possuem uma avaliação positiva ou negativa sobre o fenômeno em estudo. As perguntas do questionário que elaboramos para aferir as crenças e as atitudes linguísticas dos estudantes perante cada tipo de monotongação, foram as seguintes:

1. Falar dessa forma é comum onde você mora?

2. Você fala assim? Caso a pessoa tenha respondido não, pergunte por quê?

3. O que você acha desse jeito de falar?

4. Você acha que esse jeito de falar é típico de algum lugar? E aqui em Sergipe?

5. Você acha que esse modo de falar tem a ver com o nível de estudo da pessoa? Por quê?

6. Você acha que as pessoas que falam desse modo sofrem preconceito? Por quê?

Durante a realização dos testes (os quais foram gravados), primeiramente, pronunciávamos as palavras com a monotongação em ditongo decrescentes ("cenôra", "ôro", "dotor") e, depois, fazíamos essas seis perguntas; e, posteriormente, fazíamos o mesmo com a monotongação em ditongo crescente, usando as palavras "poliça", "paciença", "ciença". Tais perguntas foram elaboradas com base nos estudos de Cardoso (2015) e de Freitag e Santos (2016). As perguntas 1 e 2 estão relacionadas ao emprego do fenômeno, as quais envolvem as noções de percepção e crenças; ao questionamento 3, vinculam-se os aspectos estéticos/de adequação ("bonita", "feia", "correta", "errada", "estranha", "engraçada", "cultural" etc), ou seja, qual o julgamento do fenômeno; a pergunta 4 refere-se ao aspecto geográfico, isto é, se o falante associa as realizações do fenômeno a uma determinada região geográfica de acordo com a sua percepção; já os questionamentos 5 e 6 relacionam-se aos aspectos sociais, através dos quais objetivamos saber do informante se o modo de falar as formas em estudo está relacionado ao grau de escolaridade da pessoa e se os indivíduos que as utilizam podem sofrer alguma coerção social, focalizando também a percepção. No presente artigo, só não estamos utilizando o questionamento 4, o qual remete ao aspecto geográfico.

Os dados, concernentes às respostas dos informantes a cada pergunta sobre a monotongação dos ditongos crescente e decrescente, foram tabulados e submetidos ao programa estatístico RStudio ${ }^{3}$.

\section{Resultados e discussão}

Nesta seção, apresentamos os resultados e discussão referentes às atitudes linguísticas dos estudantes sobre o fenômeno da monotongação em ditongos crescentes (polícia poliça) e decrescentes (cenoura cenôra). Os resultados estão dispostos em 3 subseções, a saber: emprego do fenômeno, aspecto estético/adequação e, por fim, aspecto social.

3 Trata-se de um software desenvolvido em interface funcional para R, o qual possui uma linguagem de programação para a geração de gráficos e cálculos estatísticos. 


\section{Emprego do fenômeno}

No teste de atitude linguística, havia duas perguntas relacionadas ao emprego do fenômeno. A pergunta referente ao uso de a forma monotongada dos ditongos decrescentes e crescentes ser comum onde os estudantes moram visava identificar qual era a percepção que eles possuíam do fenômeno, ou seja, se eles conseguiam perceber o uso do fenômeno na comunidade. A segunda pergunta tinha objetivo de identificar se os estudantes acreditavam que eles mesmos usavam ou não o fenômeno, isto é, a sua crença. Os excertos a seguir apresentam algumas respostas dos estudantes quanto ao fenômeno:

(1) INF: mais padrão a língua- quando a pessoa ouve já entende fica um negócio bem padrão (ms.40) - monotongação em ditongo decrescente.

(2) INF: é comum pra pessoas mais velhas onde eu moro minha vó meus avós assim têm a mania de falar assim poliça o meu pai também acho que ele fala poliça (...) (fs.22) monotongação em ditongo crescente.

Em (1), o estudante acredita que onde ele mora as pessoas falam a forma monotongada do ditongo [ow] e a forma está presente em seu dia a dia, e a considera como "certa". Já, em (2), a informante alega que é comum o uso da forma reduzida do ditongo crescente onde mora, entretanto, ela acredita que apenas as pessoas mais velhas falam a forma monotongada. Vejamos, então, os resultados obtidos.

No que concerne ao emprego das formas monotongadas do ditongo decrescente e crescente pelas pessoas onde os estudantes residem ou se é comum onde elas moram, os resultados evidenciaram que a percepção dos estudantes sobre as duas formas reduzidas dos ditongos é bem distinta, como mostra o gráfico a seguir:

Gráfico 1: Percepção sociolinguística do emprego da monotongação decrescente e crescente na cidade em que o falante mora

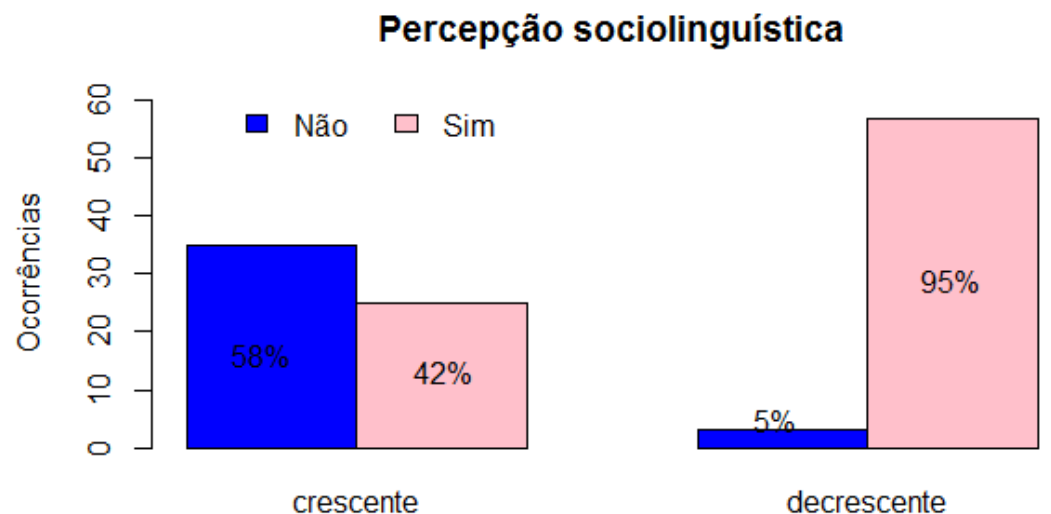

Fonte: Elaborado pelas autoras. 
Observa-se, no gráfico 1, que $95 \%$ dos estudantes afirmaram que há o uso da forma monotongada de [ow] onde residem, já $5 \%$ dos estudantes acreditam que não. Diferentemente acontece em relação à redução do ditongo crescente, pois $58 \%$ dos estudantes mencionaram que os moradores da cidade em que eles residem não utilizam o fenômeno e $42 \%$ responderam que sim. Isso evidencia que, provavelmente, a monotongação em ditongo crescente é mais estigmatizada na comunidade do que em ditongo decrescente.

Quando questionados se eles mesmos utilizam a monotongação decrescente e crescente, os resultados se modificam, principalmente, a respeito do segundo tipo, como se pode observar no gráfico abaixo:

Gráfico 2: Emprego da monotongação decrescente e crescente pelo falante

\section{Crença}

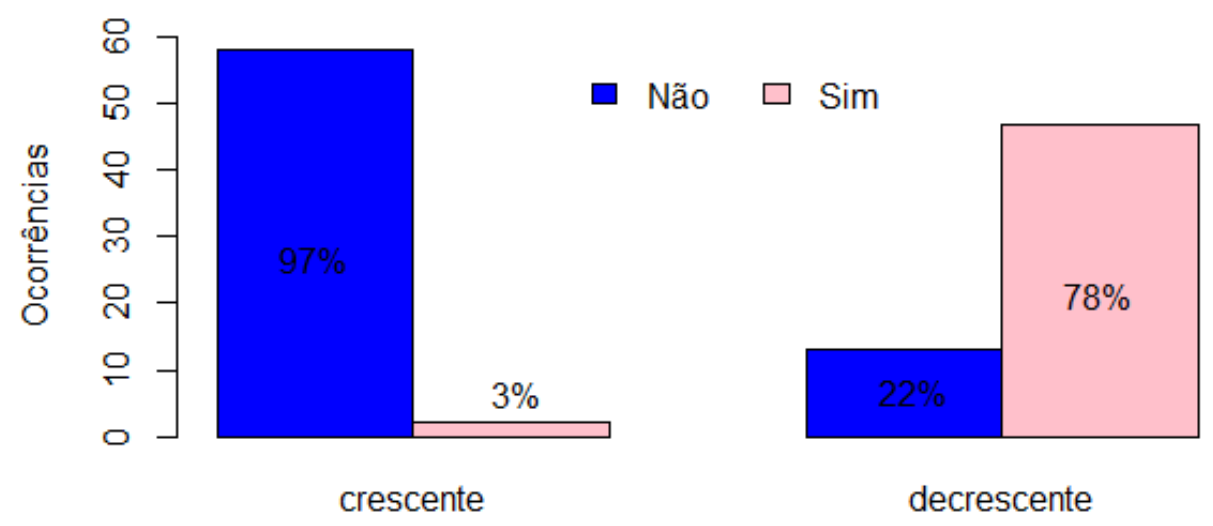

Fonte: Elaborado pelas autoras.

Em relação à monotongação do ditongo crescente, o gráfico 2 evidencia que $97 \%$ dos estudantes afirmaram não utilizar a forma reduzida do ditongo e apenas 3\% afirmam usar. O contrário foi demonstrado pelos estudantes quanto à monotongação do ditongo [ow], em que cerca de $78 \%$ deles acreditam utilizar a forma reduzida do ditongo, no entanto, $22 \%$ afirmam não usarem. Confiramos os trechos a seguir com respostas dos estudantes sobre a forma não canônica do ditongo crescente:

(3) INF: porque não sei eu acho que porque eu convivo muito com pessoas- hoje eu convivo mais com pessoas entre- mais da minha idade dificilmente você vai ver alguém que fale assim pelo menos da minha faixa etária essa- essa- essa pronúncia é comum mais onde eu vivo entre os mais velhos (fs.20).

(4) INF: porque eu não estou acostumado desse jeito geralmente quem fala assim às vezes acho que até mais quem mora na zona rural eu acredito ou pessoas analfabetas não- não querendo tipo assim falar com preconceito não que a pessoa não pode julgar ninguém mas 
acho que geralmente os analfabetos e as pessoas que vivem assim na zona rural falam predomina né (ms.55).

Em (3), a informante alega que, no seu meio de interação, ela convive mais com pessoas da sua faixa etária, isto é, com pessoas mais jovens, e que as pessoas dessa faixa etária não falam dessa forma. Já em (4), o estudante crê que quem fala dessa maneira são as pessoas analfabetas ou as que moram na zona rural e, nesse ambiente, ele acredita que é mais predominante as pessoas falarem a forma monotongada do ditongo crescente. Verifica-se, portanto, que alguns estudantes justificaram não utilizar o fenômeno relacionando à idade ou à escolaridade.

Vale ressaltar que, quando questionados do porquê de não falarem desse modo, muitos dos falantes fizeram correlação com a dicotomia do "certo versus errado" e disseram que aprenderam a forma "correta" na escola. Os excertos a seguir comprovam isso:

(5) INF: eh... é errado né não são palavras- poliça agora se fosse polícia né é uma coisa mais certa (fs.01).

(6) INF: então porque a gente aprende que não é engolindo as palavras como você falou é o normal é falar a forma correta da palavra (fs.03).

Dessa forma, os resultados das atitudes dos informantes sobre a redução do ditongo crescente corroboram o estudo feito por Moura (2017), no qual ela avaliou a atitude linguística de estudantes (calouros e concluintes) do curso de Letras, observando os três componentes da atitude (cognitivo, afetivo e comportamental). Os resultados evidenciaram atitudes negativas tanto dos calouros quanto dos concluintes embora a autora ressalte que os dados obtidos referentes aos calouros podem ter sofrido alguma influência, porque, antes da aplicação dos testes, a turma caloura já tinha passado por discussões sobre o tema variação/mudança linguística.

Alguns estudantes também correlacionaram o não uso da forma monotongada do ditongo [ow] à escolaridade, como pode ser visto em (7) e (8):

(7) INF: devido ter o grau de escolaridade ter estudado ter sido cobrado falar de tal forma em alguns momentos (fs.30).

(8) INF: não sei acho que também influencia a escolaridade os anos daí a gente vai deixando pra trás um pouquinho dos hábitos mas antes sim quando tiver em casa também falando assim daí você acaba pegando o vício (fs.15).

Percebemos que os informantes acreditam que a escolaridade pode influenciar o modo de falar e, com o passar dos anos, acabam deixando alguns hábitos, mas, quando estão em um ambiente informal, como em casa, podem reproduzir, sim, o fenômeno.

Vale mencionar que alguns dos informantes tiveram uma interpretação diferente do esperado quando ouviram a pergunta que continha o contexto "cenôra", "ôro", "dotor", referente à monotongação do ditongo decrescente, ser reproduzida pelo pesquisador, como podemos constatar nos excertos a seguir. 
(9) INF: normal é o nome- o nome do alimento do- o material aí é o ôro e dotor é o que se chama médico geralmente se chama de dotor (fs.47).

(10) INF: acho que em todo canto- em todo canto não porque algum vai puxar doutor doutor ouro cenoura já fica nivelado em alguns cantos do Brasil vão falarem normal mas em outros vão puxar o erre vão puxar o essi (fs.40).

Em (9), o estudante avalia a forma "cenôra", "ôro", "dotor" semanticamente, ou seja, o seu significado. Já o informante (10) atentou-se para a pronúncia do R nas palavras, alegando que, em outros lugares do Brasil, as pessoas podem pronunciar de uma maneira diferente. Tais respostas evidenciam que, para estes informantes, o fenômeno não é saliente.

É importante ressaltar que, mesmo que os informantes neguem a utilização da monotongação em ditongos crescentes e decrescentes ou, no momento de responderem, tenham interpretado de maneira diferente, em suma, foi perceptível uma aceitação maior do fenômeno da monotongação no ditongo [ow] do que em relação à forma monotongada do ditongo crescente - "poliça", "paciênça", "ciênça". Isso porque quando perguntado aos informantes se utilizavam a forma monotongada e se a forma variável é comum no lugar onde eles moram, as respostas de boa parte dos falantes entrevistados foram negativas.

A seguir, analisamos a atitude dos informantes em relação ao aspecto estético sobre a monotongação em ditongos crescentes e decrescentes.

Aspecto estético/de adequação

Através da pergunta "O que você acha desse jeito de falar?", foi possível verificar qual o julgamento dos informantes frente ao fenômeno - monotongação em ditongos decrescentes e crescentes - com base nas respostas que englobam o aspecto estético (bonita, feia), o aspecto de adequação (normal, correto, errado) ou o uso de outras palavras (estranho, engraçado, diferente, agressivo, cultural, praticidade, caipira, informal etc). No gráfico 3, estão expostos os resultados obtidos através desse questionamento. 
Gráfico 3: Julgamento do falante sobre a forma monotongada do ditongo decrescente e crescente

\section{Julgamento do fenômeno}

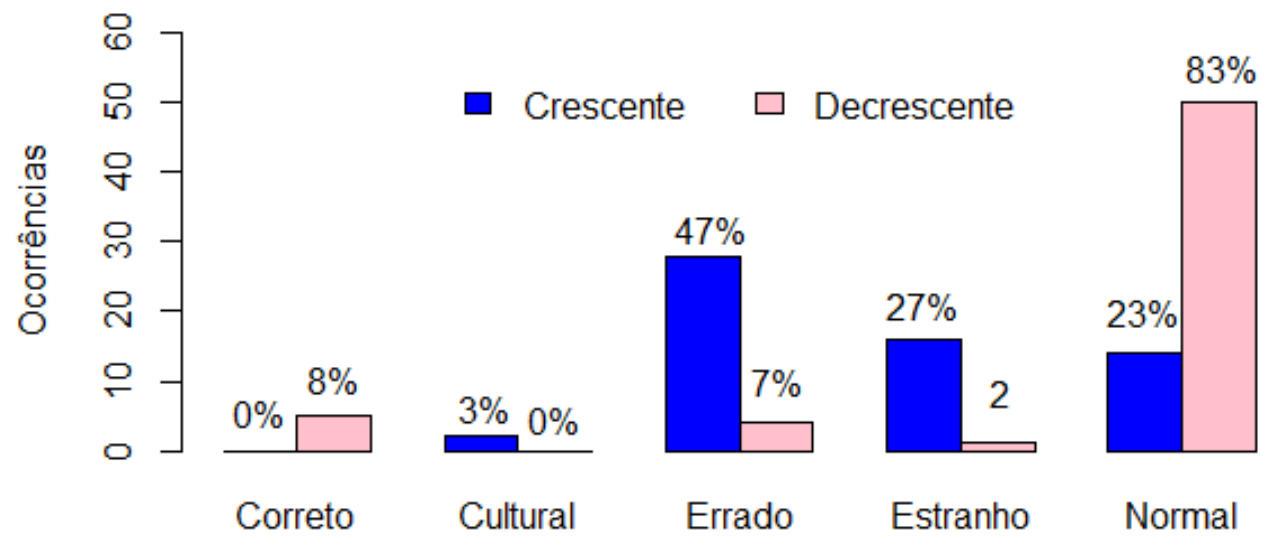

Fonte: Elaborado pelas autoras.

Conforme o gráfico 3, os resultados evidenciam que, no tocante à monotongação do ditongo crescente, $47 \%$ dos estudantes avaliaram a forma como "errada", 27\% como "estranha" e 23\% como "normal" e 3\% como "cultural". Nenhum estudante julgou a forma como correta e a maioria a considerou como errada, o que evidencia que o fenômeno é estigmatizado na comunidade estudantil. A título de exemplificação, os trechos abaixo trazem algumas respostas dadas pelos estudantes:

(11) INF: eh... pro senso comum do cotidiano pras pessoas se relacionarem eu acho normal mas se você for pra uma coisa acadêmica isso já eh... já se torna mais errado no caso (ms.34).

(12) INF: eu conheço uma pessoa que falava assim mas por fato de problemas na língua do modo de falar então eu acho também que vem de cada um (fs.27).

A partir das respostas presentes em (11) e (12), vemos que os estudantes têm consciência do fenômeno, mas o avaliam de formas distintas. Em (11), o estudante acredita que a forma reduzida do ditongo crescente só pode ser utilizada em contextos mais informais ou como o falante coloca: "do cotidiano pras pessoas se relacionarem" e que, se utilizado no meio acadêmico, ele acrescenta que "já se torna mais errado". Portanto, fica evidente que o estudante faz uma correlação com os contextos de uso formalidade ou informalidade. Já em (12), observamos que a estudante acredita que as pessoas que falam assim é porque têm algum tipo de limitação física.

No entanto, quando se trata da monotongação em ditongo decrescente, como em "cenôra", "ôro", "dotor", os estudantes avaliaram a forma mais positivamente - $82 \%$ deles julgaram a forma como "normal" e $8 \%$ como "correta". No entanto, 7\% dos falantes avaliaram a forma como "errada", já os 3\% referem-se a outras avaliações que o fenômeno recebeu, como "bonito" e "prático". Nenhum informante julgou a forma monotongada como "engraçada", "estranha", "diferente". Os excertos a seguir expõem algumas das respostas obtidas a esse respeito: 
(13) INF: acho que pra cá é algo normal você vai ouvir muito então torna corriqueiro (ms.59).

(14) INF: acho que é algo certo que tá ligado ao meu cotidiano é algo certo cenoura ouro (ms.60).

Os estudantes (ms.59, ms.60, fs.14), ao explicarem seu julgamento sobre a forma reduzida de [ow], alegaram que é algo "normal" e "certo" e a forma se encontra corriqueiramente no seu cotidiano. Dessa forma, vemos que a monotongação do ditongo decrescente é mais aceita, embora $7 \%$ dos estudantes tenham avaliado a forma como "errada". Na seção a seguir, explanamos os resultados obtidos com as perguntas que envolviam aspectos sociais.

\section{Aspecto social: escolaridade e preconceito}

Para mensurarmos a atitude dos estudantes sobre os aspectos sociais - escolaridade e preconceito -, foram feitas as seguintes perguntas aos estudantes: "você acha que esse modo de falar tem a ver com o nível de estudo da pessoa?", no intuito de sabermos se o uso do fenômeno da monotongação de ditongos decrescentes e crescentes está relacionado ao nível de escolaridade do indivíduo; e "você acha que as pessoas que falam desse modo sofrem preconceito?", a fim de sabermos se os estudantes consideram que as pessoas que falam a forma monotongada dos ditongos podem sofrer alguma coerção social. Confiramos o gráfico a seguir:

Gráfico 4: Percepção da influência da escolaridade na monotongação do ditongo decrescente e crescente

\section{Percepção do fator escolaridade}

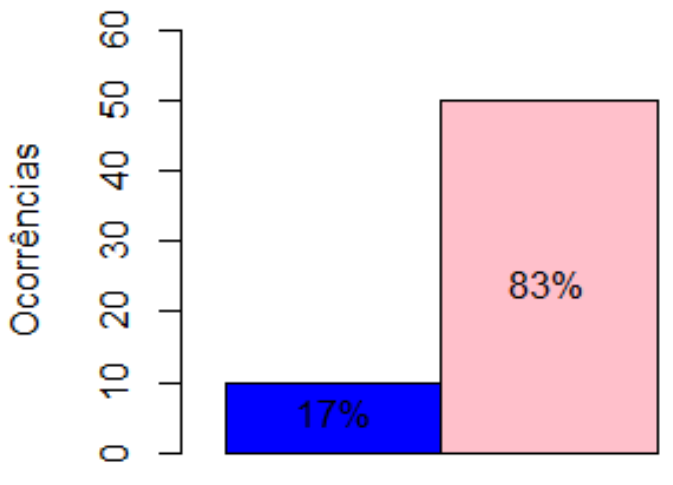

crescente

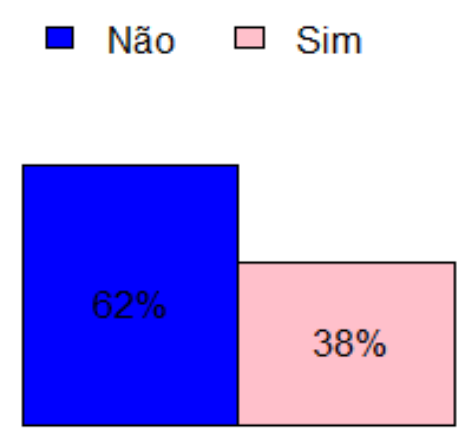

decrescente

Fonte: Elaborado pelas autoras.

Em relação à monotongação do ditongo decrescente [ow], os resultados dispostos no gráfico 4 mostram que $62 \%$ dos estudantes acreditam que a escolaridade não influencia o modo como as pessoas pronunciam a forma reduzida do ditongo: entre eles, os estudantes ms.37 e fs.01, que alegaram que 
"muita gente que não estuda também fala certo fala correto" e que "a gente hoje em dia não aprende tudo na escola aprende muita coisa também fora (...) no cotidiano", respectivamente. Entretanto, 38\% dos informantes afirmaram que o nível de estudo da pessoa influencia o modo de falar a forma reduzida do ditongo [ow]. Santiago (2017) aplicou um teste de atitude para estudantes do 60, $9^{\circ}$ e $3^{\circ}$ anos da educação básica com intuito de verificar se estes achavam que a pessoa que fala o fenômeno era muito/bastante escolarizada ou não ${ }^{4}$. Os resultados evidenciaram que $66,7 \%$ dos estudantes, tanto do $6^{\circ}$ ano quanto do 90 ano, afirmaram que a pessoa que fala a forma monotongada é muito/bastante escolarizadae $53,3 \%$ dos estudantes do $3^{\circ}$ ano fizeram a mesma avaliação. Tais resultados são condizentes não só com os obtidos na presente pesquisa, mas também com os obtidos pelos estudos variacionistas feitos sobre a produção do fenômeno na fala dos informantes (cf. JESUS et al, 2010; SANTOS; CHAVES, 2010; CRISTOFALINI, 2011 etc), pois estes mostraram que, além de não haver relevância da variável escolaridade para que haja a redução do ditongo decrescente, a supressão do glide apresenta-se cada vez mais categórica (FARIAS; OLIVEIRA, 2003; PEREIRA, 2004).

Quanto à monotongação do ditongo crescente em contextos como "poliça", "paciênça", "ciênça", os resultados (gráfico 4) evidenciaram que $83 \%$ dos estudantes acreditam que o nível de estudo influencia no modo como as pessoas falam a forma monotongada do ditongo (como exemplificado em (16) e (17), entretanto, $17 \%$ alegaram que não. Nenhum dos informantes afirmou que a escolaridade tem pouca/talvez influência em falar a forma reduzida.

(16) INF: é mais questão social mesmo né nível de estudo não (fs.02).

(17) INF: sim porque as pessoas que eu vi falando são pessoas mais de idade e eles ti- eu sei que eles tiveram o nível de escolaridade baixa (ms.52).

Portanto, os resultados nos revelaram que a maioria dos estudantes acredita que as pessoas falam desse jeito porque não tiveram acesso à escola e, por isso, não sabem falar a forma "correta". Um resultado semelhante foi encontrado por Moura (2017), em seu estudo sobre a atitude de estudantes de Letras (calouros e concluintes) sobre pessoas que pronunciam as palavras paciênça/poliça. $O$ estudo da autora mostrou que, no julgamento da escolaridade, as atitudes, tanto dos calouros quanto dos concluintes, foram negativas com um percentual de $56 \%$ e $64 \%$, respectivamente.

No gráfico a seguir, expomos nossos resultados a respeito do aspecto social preconceito, através do qual foi possível identificar se os estudantes consideram que as pessoas que falam as formas monotongadas dos ditongos podem sofrer preconceito linguístico ou não.

\footnotetext{
${ }^{4}$ Santiago (2017) apresenta os resultados referentes a essa questão separando as respostas dos informantes em: pouco, muito ou bastante escolarizado. Para uma melhor explanação, juntamos os resultados das respostas relacionadas a muito e bastante escolarizada.
} 
Gráfico 5: Percepção do preconceito linguístico quanto ao uso da monotongação do ditongo decrescente e crescente

\section{Percepção do preconceito linguístico}

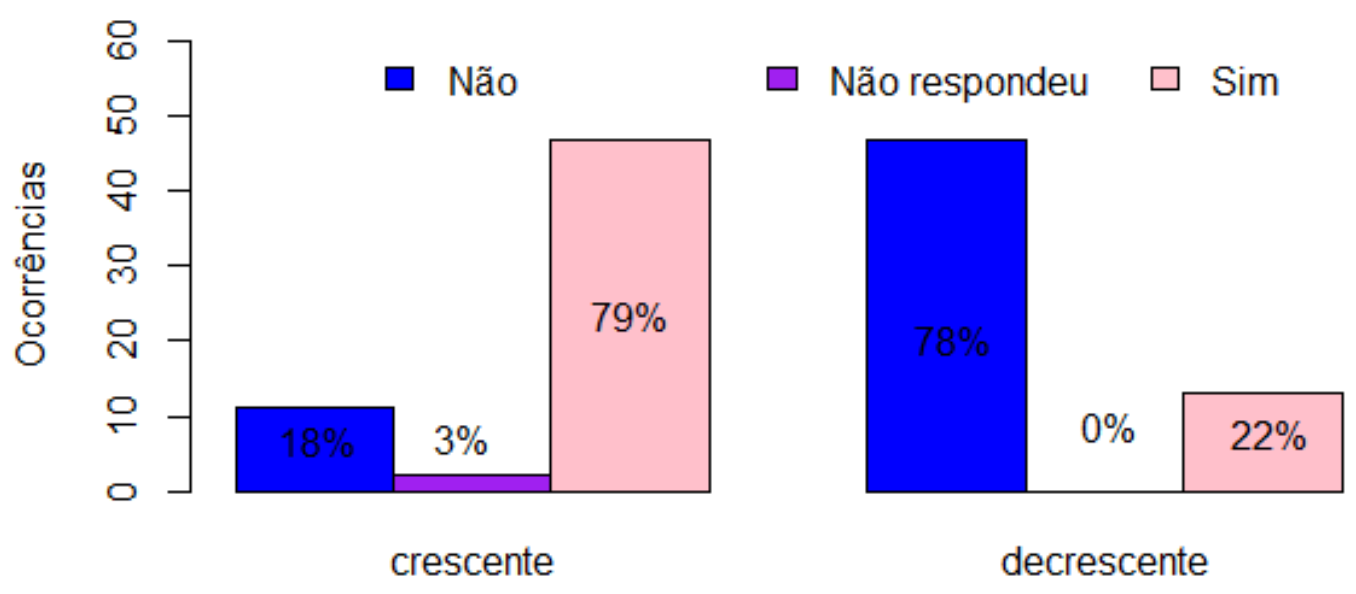

Fonte: Elaborado pelas autoras.

Quando perguntado aos estudantes se as pessoas que falam a forma reduzida do ditongo decrescente sofrem preconceito, os resultados, presentes no gráfico 5, revelaram que cerca de $78 \%$ deles acreditam que não (18) e (19) e $22 \%$ que sim (20) e (21).

(18) INF: é normal tem- dá pra entender se você falar alguma coisa absurda que não dê pra as pessoas entenderem é complicado né (fs.02).

(19) INF: porque eu nunca vi ninguém sofrendo preconceito porque falô assim (fs.04).

(20) INF: porque assim pode ser olhada outro- com maus olhos "ah aquela pessoa é do sítio e não sei o quê" tipo assim (fs.13).

(21) INF: porque não tá pronunciando a palavra totalmente correta (fs.19).

Constatamos, então, que, mesmo que alguns informantes achem que as pessoas podem sofrer preconceito por falarem a forma monotongada do ditongo decrescente, ainda assim, tendo consciência ou não do fenômeno, a forma reduzida de [ow] demonstra ser mais aceita e ter atitude dos estudantes mais positivas. Algo que pode justificar isso, segundo Santiago (2017), é o fato de os fenômenos menos perceptíveis, como é o caso da monotongação de ditongos decrescentes, serem também os menos estigmatizados, portanto aqueles que o utilizam está menos passível de sofrer preconceito linguístico.

Diferentemente observamos, em relação à monotongação do ditongo átono final, como em "poliça", "paciênça", "ciênça", porque os resultados, conforme gráfico 5, nos mostraram que cerca de 79\% dos estudantes acreditam que as pessoas que falam a forma reduzida do ditongo crescente podem sofrer preconceito linguístico (como se verifica nos exemplos em (22) e (23)). No entanto, 18\% dos estudantes creem que as pessoas não sofrem qualquer tipo de coerção social (exemplo (24)) e apenas 3\% não responderam ou não souberam responder ao questionamento. 
(22) INF: por que elas devem sofrer? porque é horrível ser uma pessoa falando desse jeito porque nem quem fala errado fala paciência desse jeito é uma vergonha até para quem fala errado (ms.32).

(23) INF: porque às vezes tem alguém que que no caso que sabe falar oh... de acordo com ah... no caso de uma forma de uma maneira mais formal e gosta de debochar esse sim é um caso que pode acontecer um bullying um bullying (ms.36).

(24) INF: não vejo ninguém sofrer preconceito não é bem aceito as pessoas entendi o que a pessoa quis dizer não é aquela palavra que você diz uma coisa e na verdade é outra você fica sem saber o que realmente a pessoa quis dizer então (fs.02).

Destarte, a avaliação negativa sobre a monotongação em ditongo crescente é maior do que a positiva. Isso está correlacionado, provavelmente, ao fato de que a saliência entre as vogais é mais perceptível (cf. HORA, 2012) em contextos como o de "poliça", "paciênca", "ciênca" e possuir menor prestígio social. Consequentemente, a depender do grau de saliência do fenômeno na comunidade, o falante que a utilizar será mais suscetível de sofrer preconceito linguístico. Na seção a seguir, tecemos nossas considerações finais a respeito dos resultados obtidos.

\section{Considerações finais}

Neste trabalho, procuramos mensurar as crenças e as atitudes linguísticas dos universitários quanto à monotongação em ditongos crescentes e decrescentes. Os resultados evidenciaram que os falantes têm consciência da ocorrência do fenômeno da monotongação em ditongos crescentes e decrescentes. No entanto, constatamos que a percepção do uso da monotongação em ditongo [ow] é maior do que em relação ao ditongo crescente.

Quanto ao emprego do fenômeno pelos falantes (crença), os resultados mostraram que, em relação à forma reduzida de [ow], os informantes afirmaram que a utilizam e ela é comum onde eles residem. Diferentemente ocorre em relação a monotongação no ditongo crescente, porque, em sua maioria, os estudantes alegaram que não falam a forma monotongada. No que se refere ao aspecto estético/de adequação, a monotongação de [ow] foi avaliada mais positivamente, como "normal", "correta". Ao contrário do que aconteceu com a monotongação de ditongos crescentes [ja], que obteve julgamentos mais negativos, como "errada", "estranha".

Já para os aspectos sociais, os dados revelaram que, em relação à redução do ditongo decrescente, os estudantes afirmaram que a escolaridade não influencia o modo como as pessoas pronunciam a forma reduzida do ditongo. Quando questionados se as pessoas que falam dessa maneira sofrem preconceito, alguns informantes afirmaram que sim, mas, ainda assim, mesmo tento consciência ou não do fenômeno, a forma reduzida de [ow] demonstrou ser mais aceita e possuir atitude dos estudantes mais positivas, e que o falante que utilizá-la é menos passível de sofrer preconceito linguístico.

No que concerne à monotongação do ditongo crescente, a avaliação sobre esta demonstrou ser mais negativa do que positiva; isso acontece porque a saliência vocálica em "poliça", "paciênca", "ciênca" é mais perceptível (Cf. HORA, 2012) pelos falantes e, por isso, a forma é avaliada como de menor 
prestígio e mais suscetível ao preconceito linguístico. Além do mais, os resultados nos revelaram que a maioria dos estudantes acredita que as pessoas que falam desse jeito porque não tiveram acesso à escola e que por isso não sabem falar a forma "correta".

Dessa forma, conclui-se que, a saliência do fenômeno da monotongação em ditongos crescentes e decrescentes na comunidade estudantil é distinta. Isto é, os resultados evidenciaram que, considerando a teoria postulada por Labov (2008), a forma reduzida do ditongo crescente, como em "poliça", "paciênça", "ciênça", demonstra ter comportamento de estereótipo na comunidade estudantil devido à sua forte saliência social, visto que a forma reduzida revelou-se ser bastante estigmatizada pelos falantes. Já em relação a monotongação em ditongo decrescente, sobretudo em [ow], parece ter comportamento de indicador, porque a avaliação social que a maioria dos falantes faz da forma é positiva e não a estigmatiza, e que as pessoas que utilizam a forma monotongada do ditongo não sofrem preconceito linguístico. Acreditamos, portanto, que isso possa ter relação com o fato de que a variação desse ditongo já seja praticamente categórica, uma possível mudança em progresso, pois pesquisas têm demonstrado que a supressão do glide está acontecendo cada vez mais independentemente de fatores sociais ou linguísticos (FARIAS; OLIVEIRA, 2003; PEREIRA, 2004).

\section{Referências}

ALKMIN, T. M. Sociolinguística. Parte I. In: MUSSALIM, F.; BENTES, A. C. (orgs.). Introdução à linguística: domínios e fronteiras. São Paulo: Cortez, 2001. p. 21-47.

AMARAL, M. P. do. Ditongos variáveis no sul do Brasil. Letras de Hoje. Porto Alegre, v. 40, n. 3, p. 101-116, set. 2005.

BARCELOS, A. M. F. Reflexões acerca da mudança de crenças sobre ensino e aprendizagem de línguas. Rev. Brasileira de Linguística Aplicada, v. 7, n. 2, p. 109-138, 2007.

BOTASSINI, J. O. M. A importância dos estudos de crenças e atitudes para a sociolinguística. SIGNUM: Estud. Ling., Londrina, n. 18/1, p. 102-131, jun. 2015.

CARDOSO, D. P. Atitudes linguísticas e avaliações subjetivas de alguns dialetos Brasileiros. $1^{\text {a }}$ ed. São Paulo: Editora Edgar Blücher, 2015. 145p.

CRISTÓFARO SILVA, T; FARIA, I. Percursos de ditongos crescentes no português brasileiro. Letras de Hoje, Porto Alegre, v. 49, n. 1, p. 19-27, jan./mar. 2014

CRISTOFOLINI, C. Estudo da monotongação de [ow] no falar florianopolitano: perspectiva acústica e sociolinguística. Disponível em: <http://revistas.ufpr.br/abralin/article/viewFile/32070/20409> Acesso em: 31 dez. 2017.

FARIAS, M. A. Ro. de; OLIVEIRA, M. B. de. Variação fonética dos ditongos [ej] e [ow] no nordeste do Pará. Disponível em: <http://www.filologia.org.br/viicnlf/anais/caderno1019.html>. Acesso em: 31dez. 2017

FREITAG, R. M. K..; SANTOS, A. de O. "Percepção e atitudes linguísticas em relação às africadas pós-alveolares em Sergipe", p. 109-122. In: A Fala Nordestina: entre a sociolinguística e a dialetologia. São Paulo: Blücher, 2016.

HORA, D. Monotongação de ditongos crescentes: realidade linguística e social. In LOBO, T., CARNEIRO, Z., SOLEDADE, J., ALMEIDA, A., and RIBEIRO, S., (orgs.) Rosae: linguística histórica, história das línguas e outras histórias [online]. Salvador: EDUFBA, 2012, p. 349-356.

JESUS, A. A. de; SANTOS, C. dos; SANTOS, M. de O. O processo de monotongação na fala dos estudantes universitários - UFS/Itabaiana: uma abordagem sociolinguística. In: I Encontro Interdisciplinar de Língua e Literatura - I ENILL, 2010. Itabaiana: DLI, 2010. p. 21-21.

LAMBERT, W. W.; LAMBERT, W. E. Psicologia social. Rio de Janeiro: Zahar Editores, 1972. 172p.

LABOV, W. Padrões sociolinguísticos. Trad. BAGNO, M.; SCHERRE, M.; CARDOSO, C. $1^{\text {a }}$ ed. São Paulo: Parábola Editorial, 2008 [1972]. 392p.

LOPES, R. A realização variável dos ditongos /ow/ e /ej/ no português falado em Altamira/PA. 2002. 97f. Dissertação (Mestrado em Linguística), UFPA, Belém, PA, 2002.

LÓPEZ MORALES, H. Sociolingüística. $3^{a}$ ed. Madrid: Gredos, 2004 apud BOTASSINI, J. O. M. A Importância dos Estudos de Crenças e Atitudes para a Sociolinguística. SIGNUM: Estud. Ling., Londrina, 2015. 
LOURENÇO, D. S. Crenças e atitudes linguísticas: uma análise sobre o corpus oral mineiro. Disponível em: $<$ http://docplayer.com.br/39420968-Crencas-e-atitudes-linguisticasuma-analise-sobre-o-corpus-oralmineiro.html> Acesso em: $07 \mathrm{dez} .2017$.

MARQUES, T. M; BARONAS, J. E. de A. Crenças e atitudes linguísticas na sala de aula. Linguasagem, São Carlos, v. 24 (1), p. 1-16, 2015.

MOURA, E. S. V. Atitudes linguísticas de graduandos em Letras em relação à redução do ditongo final [ja] em palavra paroxítona e às pessoas que a empregam. 2017. 97f. Tese de doutorado, Natal, RN, 2017.

PEREIRA, G. A monotongação dos ditongos <ej>, <ow> e <aj> no português falado em Tubarão (SC): estudo de casos. 2004. 134f. Dissertação (Mestrado em Ciências da Linguagem), UNISUL, Tubarão, SC, 2004.

SANTIAGO, V. de A. Eu não falo assim: produção e percepção sociolinguísticas de estudantes do ensino fundamental e médio. 2017. Trabalho de Conclusão de Curso (Licenciatura em Letras) - Universidade Federal de Sergipe. 2017.

SANTOS, C. L. F; CHAVES, M. L. O processo da monotongação nos falares de Plácido Castro (AC). Revista Philologus. Rio de Janeiro: CiFEFiL, Ano 16, no 46, Supl. p. 100-115, 2010.

TOLEDO, E. E. A monotongação do ditongo oral decrescente /ej/ em Porto Alegre. Cadernos do IL. Porto Alegre, n. ${ }^{\circ} 40$, p. 134-160, jun. 2010.

WEINREICH, U; LABOV, W; HERZOG, M. Fundamentos empíricos para uma teoria da mudança linguística. Trad. BAGNO, M. $1^{\text {a }}$ ed. São Paulo: Parábola, 2006. 153p. 